\title{
PENGARUH DIMENSI KUALITAS PELAYANAN JASA \\ TERHADAP KEPUASAN DAN MINAT DATANG KEMBALI KONSUMEN PADA DEALER WIRA MEGAH TOYOTA PROFITAMAS PALANGKA RAYA
}

\author{
Isra Misra ${ }^{1}$
}

\begin{abstract}
This research aims to see the Influence of Service Quality Dimension on Satisfaction and Consumers' Cause Back Against The Wira Megah Car Workshop Toyota Profitamas Palangka Raya Branch.

This research is a quantitative research using descriptive quantitative approach. Analysis tool in this research is Smart PLS (Path Analysis) application. The research variables consist of Quality of Service (X), Consumer Satisfaction (Y1) and Come Back (Y2) as mediation variable. Samples use Accidental Sampling method as many as 100 samples from all customers of Toyota Workshop Palangka Raya.

Result of research of service quality constructively can influence customer's satisfaction which have implication on intention come back in accordance with outer loading analysis result $0,867(86,7 \%)$. Similarly, customer satisfaction variables have been able to explain and mediate quality of service variables with outer loading of $0.925(92.5 \%)$. While for the intention variable comes back own value of outer loading equal to $0,922(92,2 \%)$ The information indicate that statistically test service of new service to workshop is the highest indicator in describing variable of intention come back again.
\end{abstract}

\section{Keywords: service quality, consumer satisfaction and intentions coming back}

\section{PENDAHULUAN}

Dunia bisnis layanan merupakan faktor kunci dalam memenangkan pasar. Pelayanan merupakan sektor jasa yang mampu memberikan stimulus terhadap kinerja perusahaan. Dengan pelayanan prima maka perusahaan mampu bersaing secara menyeluruh. Pelayanan menjadi fenomena yang terus menjadi fokus masing-masing perusahaan.

Pelayanan yang baik terhadap konsumen merupakan salah satu bentuk tanggung jawab perusahaan. Namun, tidak sedikit dari perusahaan yang belum memberikan pelayanan yang baik terhadap konsumen. Pelayanan yang baik tentu akan memberikan hal yang baik pula untuk perusahaan, karena pelayanan ini merupakan wujud tanggung jawab sosial perusahaan, maka ini dapat memberikan keuntungan tersendiri untuk perusahaan.

Definisi pelayanan adalah setiap tindakan atau kegiatan yang dapat ditawarkan oleh suatu pihak kepada pihak lain, yang pada dasarnya tidak berwujud dan tidak mengakibatkan kepemilikan apapun. Produksinya dapat dikaitkan atau tidak dikaitkan pada satu produk fisik. Pelayanan merupakan perilaku produsen dalam rangka memenuhi kebutuhan dan keinginan konsumen demi tercapainya kepuasan pada konsumen itu sendiri. Kotler juga mengatakan bahwa perilaku tersebut dapat terjadi pada saat, sebelum dan sesudah terjadinya transaksi. Pada umumnya pelayanan yang bertaraf tinggi akan menghasilkan kepuasan yang tinggi serta pembelian ulang yanglebih sering. Kata kualitas mengandung banyak definisi dan makna, orang

${ }^{1}$ Dosen Fakultas Ekonomi dan Bisnis Islam IAIN Palangka Raya. 
yang berbeda akan mengartikannya secara berlainan tetapi dari beberapa definisi yang dapat kita jumpai memiliki beberapa kesamaan walaupun hanya cara penyampaiannya saja biasanya terdapat pada elemen sebagai berikut.

1. Kualitas meliputi usaha memenuhi atau melebihkan harapan pelanggan.

2. Kualitas mencakup produk, jasa, manusia, proses dan lingkungan.

3. Kualitas merupakan kondisi yang selalu berubah.

Dalam dunia bisnis layanan memiliki kinerja dimana kinerja layanan adalah kinerja dari pelayanan yang diterima oleh konsumen itu sendiri dan menilai kualitas dari pelayanan yang benar-benar mereka rasakan. Ukuran yang berdasarkan kinerja akan lebih merefleksikan kualitas jasa/pelayanan karena pengukuran terhadap kualitas pelayanan dalam SERVQUAL telah membentuk paradigma yang lemah, dimana harapan konsumen terhadap kualitas jasa mengacu kepada harapan konsumen terhadap penyedia jasa secara umum, sedangkan persepsi terhadap kinerja jasa mengarah kepada perusahaan jasa yang dituju/spesifik. Hal ini diperkuat bahwa service performance akan menjadi prediktor yang baik bagi kualitas jasa/pelayanan. Semakin service performance yang diberikan perusahaan meningkat, maka kepuasan pelanggan juga akan meningkat sehingga akan berdampak pada meningkatnya loyalitas pelanggan.

Kepuasan konsumen (Customer Satisfaction) merupakan suatu dorongan keinginan individu yang diarahkan pada tujuan untuk memperoleh kepuasan. Apabila pihak perusahaan tersebut mampu memberikan kepuasan bagi pelanggan, maka hal itu akan berdampak pada tingkat loyalitas pelanggan terhadap perusahaan, begitu sebaliknya. Hal ini sesuai bahwa konsumen akan setia atau loyal terhadap suatu merk bila ia mendapatkan kepuasan dari merk tersebut. Untuk meningkatkan kepuasan konsumen, perusahaan tersebut perlu mengatur strategi pemasaran agar pelanggan tertarik terhadap produk-produk yang ditawarkan. Strategi tersebut salah satunya dengan memperkirakan kecenderungan permintaan konsumen terhadap suatu barang atau jasa. Pemahaman terhadap kebutuhan dan keinginan konsumen merupakan dasar bagi suatu perusahaan dalam mencapai keberhasilan pemasaran produk/jasa, karena pemasaran merupakan kegiatan yang diarahkan untuk memuaskan kebutuhan dan keinginan konsumen. ${ }^{2}$

Persaingan yang semakin ketat akan membuat para pelaku bisnis menjadi harus lebih serius dalam memberikan pelayanan terhadap konsumen sehingga dapat memberikan kepuasan terhadap pelanggandan dapat memiliki nilai saing dibandingkan kompetitor. Kualitas pelayananlah yang menjadi poin utama dalam jasa perbengkelan ini, jika pelayanan diberikan secara maksimal tentu saja akan mempengaruhi loyalitas seorang konsumen. Menurut Kotler dan Keller, kualitas adalah jaminan terbaik atas loyalitas pelanggan, pertahanan terkuat perusahaan dalam menghadapi persaingan, dan satu-satunya jalan untuk mempertahankan pertumbuhan dan penghasilan.

Produk jasa yang berkualitas dinilai merupakan kunci utama dalam memenangkan persaingan,yang pada akhirnya akan dapat memberikan nilai kepuasan yang lebih tinggi kepada pelanggan. Pelanggan kini memiliki tuntutan nilai yang jauh lebih besar dan beragam karena pelanggan dihadapkan pada berbagai pilihan berupa barang maupun jasa yang dapat mereka beli. Dalam hal ini penjual harus memberikan kualitas yang dapat diterima, karena bila tidak, pelanggan akan segera beralih kepada pesaing. Keberhasilan memenangkan kompetisi sangat ditentukan oleh antisipasi pasar dan tanggapan yang cepat terhadap setiap perubahan kebutuhan maupun perilaku konsumen. Dalam menghadapi perubahan kebutuhan dan perilaku konsumen tersebut, perusahaan dituntut untuk semakin kreatif dan inovatif dalam melayani

${ }^{2}$ Kotler dan Keller, Manajemen Pemasaran, PT.Indeks Jakarta: PT.Indeks, Edisi 12, Jilid 1 2007, h. 54. 
konsumen melalui penawaran produk atau jasa dengan memberikan pelayanan yang semakin baik atau unggul.

Berdasarkan teori pemasaran, kepuasan pelanggan dapat dipengaruhi oleh berbagai faktor. Kepuasan salah satunya dapat dipengaruhi oleh kualitas layanan. Kualitas pelayanan merupakan suatu evaluasi keseluruhan terhadap fungsi dari apa yang diterima secara aktual oleh pelanggan (kualitas teknis) dan bagaimana layanan tersebut disampaikan. Untuk menilai kualitas pelayanan, para ahli pemasaran seperti Parasuraman, Zeithaml, Berry telah mengajukan beberapa dimensi-dimensi dari pelayanan yang berkualitas. Perusahaan bengkel merupakan produk jasa, maka kualitas bengkel dapat dilihat langsung dari wujud langsung, keandalan, daya tanggap, jaminan dan empati.

Faktor lain yang seringkali dikaitkan dengan upaya penciptaan kepuasan pelanggan adalah nilai pelanggan. Kotler \& Keller mengungkapkan bahwa suatu perusahaan berhasil menawarkan produk/jasa kepada pelanggan apabila mampu memberikan nilai dan kepuasan (value and satisfaction). Nilai pelanggan (value) adalah perkiraan konsumen atas seluruh kemampuan produk untuk memuaskan kebutuhannya. Oliver menjelaskan bahwa nilai produk (productvalue) dapat dirasakan oleh konsumen sewaktu konsumen membandingkan antara kinerja produk yang berdasarkan utilitasnya dengan biaya yang dikeluarkan, seperti finansial, psikologis, dan upaya untuk mendapatkan produk tersebut. Untuk itu perusahaan saling berlomba memberikan nilai tertinggi bagi konsumen, karena konsumen menginginkan nilai maksimum dengan dibatasi oleh biaya pencarian, keterbatasan pengetahuan, mobilitas, dan penghasilan. Semakin besar manfaat yang diberikan dibandingkan dengan harganya, maka semakin besar nilai yang diperolehpelanggan terhadap produk tersebut.

Kepuasan merupakan respon pelanggan terhadap evaluasi antara harapan sebelumnya dengan kinerja aktual yang dirasakan oleh konsumen. Jika kepuasan konsumen tercapai akan timbul loyalitas dari konsumen yang merupakan salah satu tujuan perusahaan. Salah satu cara agar kepuasan konsumen dapat tercapai adalah dengan meningkatkan kualitas pelayanan. Kualitas didefinisikan sebagai seberapa jauh perbedaan antara kenyataan dan harapan konsumen atas jasa yang mereka terima. Apabila perusahaan mampu memberikan jasa yang berkualitas maka hal tersebut dapat menciptakan kepuasaan pelanggan, semakin tinggi kualitas yang diberikan semakin tinggi pula kepuasan yang dirasakan.

PT. Wira Megah Toyota Profitamas adalah salah satu perusahaan yang beroperasi pada bidang otomotif terutama bidang penjualan dan service mobil Toyota. Memiliki beberapa cabang di Indonesia. Di Kalimantan PT. Wira Megah Toyota Profitamas memiliki cabang yang hampir di seluruh provinsi. Salah satu cabangnya adalah di Palangka Raya Kalimantan Tengah. PT. Wira Megah Toyota Profitamas Cabang Palangka Raya adalah salah satu dealer mobil terbesar dan terlengkap di Kalimantan Tengah. Untuk meningkatkan kepuasan pelanggan maka dealer PT. Wira Megah Toyota Profitamas selalu memberikan pelayanan prima dengan selalu memberikan services excellences kepada pelanggan setia. Hal ini tentu untuk meningkatkan kepuasan konsumen sehingga dapat meningkatkan loyalitas konsumen kepada perusahaan. Kualitas pelayanan juga menjadi prioritas penting bagi konsumen sehingga setiap tahunnya perusahaan selalu melakukan perbaikan baik dari segi fasilitas maupun dari segi tenaga pelayanan. Hal ini sesuai dengan hasil wawancara sekilas antara peneliti dan pimpinan PT. Wira Mega Toyota Profitamas Cabang Palangka Raya.

Selain dealer Wira Megah Toyota ada beberapa dealer resmi di Palangka Raya. Salah satu pesaing dealer Wira Megah Toyota adalah dealer Honda yang berada pada Jalan Adonis Samad Palangka Raya. Walaupun sama-sama produk jepang kedua dealer ini memiliki keunggulan tersendiri. Namun, secara kompetensi di Palangka Raya Toyota merupakan brand yang sangat 
besar yang sudah tertanam di benak pelanggan. Hal itu pula mengakibatkan dealer Wira Megah Toyota menjadi salah satu dealer yang sangat ramai dikunjungi oleh konsumen.

Beberapa kasus memang kualitas pelayanan berpengaruh terhadap kepuasan konsumen. Begitu pula terjadi pada perusahaan otomotif terutama divisi yang bertugas untuk memberikan pelayanan purna jual. Dengan dimensi kualitas pelayanan maka akan berdampak pada meningkatkan kunjungan konsumen. Hal ini pula yang menjadi fokus tersendiri dari pimpinan PT. Wira Mega Toyota Profitamas Cabang Palangka Raya.

Perilaku niat pelanggan terhadap produk dan jasa merupakan hasil dari proses kepuasan yang dirasakan pelanggan terhadap produk dan jasa yang telah diberikan oleh penyedia produk dan jasa. Kepuasan yang dirasakan pelanggan terhadap produk dan jasa yang telah diberikan dapat memberikan pengaruh perilaku niat pelanggan yang tinggi atau rendah tergantung seberapa besar kepuasan yang dirasakan pelanggan.

Pemahaman terhadap perilaku konsumen akan memudahkan manajemen dalam upaya untuk mengembangkan produk atau jasanya sesuai kebutuhan dan keinginan konsumen. Keinginan berperilaku konsumen seringkali didasarkan pada kemungkinan tindakan yang akan dilakukan.

Niat (intention) didefinisikan Mowen dalam Ensiklopedia, ${ }^{3}$ sebagai keinginan konsumen untuk berperilaku menurut cara tertentu dalam rangka memiliki, membuang dan menggunakan produk atau jasa. Jadi konsumen dapat membentuk keinginan untuk mencari informasi, memberitahukan orang lain tentang pengalamannya dengan sebuah produk, membeli sebuah produk atau jasa tertentu, atau membuang produk dengan cara tertentu.

Tedapat enam faktor yang mempengaruhi niat menggunakan ulang atau sering juga disebut Repurchase Intentionya itu Brand Preference, costumer loyalty, Perceived Value, Perceived Qualty, PerceiveEquity. ${ }^{4}$

Menurut Bahthiar dan Hariadi dimensi revisit intention dapat diklasifikasikan menjadi tiga dimensi, yaitu : 5

1. Continue purchasing, yaitu pengunjung yang berniat melakukan pembelian secara kontinyu atau berkala.

2. Purchase additional service, yaitu pengunjung berniat membeli jasa layanan tambahan.

3. Test new services, yaitu pengunjung yang berniat untuk menguji jasa layanan baru.

Jadi dimensi niat datang kembali terdiri dari continue purchasing, purchase additional service dan test new services. Ketiga variable di atas merupakan dimensi dalam membentuk niat datang kembali konsumen.

Menentukan kebutuhan konsumen merupakan hal penting yang harus dilakukan oleh perusahaan agar dapat menciptakan penjualan dan kepuasan konsumen. Seorang konsumen yang merasa puas akan melakukan pembelian ulang dan menceritakan hal-hal yang baik mengenai perusahaan. Dengan demikian kepuasan bisa diartikan sebagai upaya pemenuhan sesuatu atau membuat sesuatu memadai. Oleh karena itu perhatian terhadap kepuasan maupun ketidakpuasan konsumen telah menjadi penting, karena pada dasarnya tujuan dari suatu perusahaan adalah untuk menciptakan rasa puas pada konsumen. Semakin tinggi tingkat kepuasan konsumen, maka akan mendatangkan keuntungan yang semakin besar bagi perusahaan, karena pelanggan akan melakukan pembelian ulang terhadap produk perusahaan.

\footnotetext{
3 Ambika Shastri, Pengaruh Kualitas Pelayanan dan Lokasi Terhadap Kepuasan Konsumen pada Bengkel Motor. Denpasar: Paramitha Graha, Jurnal EMBA, Vol. 2 No. 2, 2012, h. 8.

4 Ferdinand, Metode Penelitian Manajemen Pedoman Penelitian untuk Penulisan Skripsi, Tesis, dan Disertasi. Semarang: Badan Penerbit Universitas Diponegoro, 2011, h. 98.

5 Asghar dkk, Studi Pengaruh Layanan Pelanggan dan Kualitas Produk Terhadap Kepuasan Pelanggan dan Loyalitas. International Journal of Humanities and Social Science Vol. 1 No. 7; [Special Issue -June 2011], 2011, h. 45.
} 
Namun apabila tingkat kepuasan yang dirasakan konsumen kecil, maka terdapat kemungkinan bahwa konsumen tersebutakan pindah ke produk pesaing. ${ }^{6}$

Menurut Kotler (2006) kepuasan konsumen adalah perasaan senang atau kecewa seseorang yang berasal dari perbandingan antara kesannya terhadap kinerja atau hasil suatu produk dengan harapan-harapannya. Jika kenyataan lebih dari yang diharapkan, maka layanan dapat dikatakan bermutu sedangkan jika kenyataan kurang dari yang diharapkan, maka layanan dikatakan tidak bermutu. Apabila kenyataan sama dengan harapan, maka layanan disebut memuaskan. Dengan demikian service quality dapat didefinisikan sebagai jauhnya perbedaan antara kenyataan dan harapan konsumen atas layanan yang mereka terima. ${ }^{7}$

Basu Swastha dan Irawan mendefinisikan kepuasan konsumen sebagai suatu dorongan keinginan individu yang diarahkan pada tujuan untuk memperoleh kepuasan. Dalam hal ini perlu diketahui bahwa suatu keinginan itu harus diciptakan atau didorong sebelum memenuhi motif. Sumber yang mendorong terciptanya suatu keinginan dapat berbeda dari diri orang itu sendiri atau berada pada lingkungannya. ${ }^{8}$ Kepuasan konsumen didefinisikan sebagai keseluruhan sikap yang ditunjukkan oleh konsumen atas barang dan jasa setelah mereka memperoleh dan menggunakannya. ${ }^{9}$

Kepuasan konsumen terhadap suatu produk ataupun jasa, sebenarnya sesuatu yang sulit untuk didapat jika perusahaan tidak benar-benar mengerti apa yang diharapkan oleh konsumen. Untuk produk atau layanan dengan kualitas yang sama, dapat memberikan tingkat kepuasan yang berbeda-beda bagi konsumen.

Pada dasarnya tujuan dari suatu bisnis adalah menciptakan agar konsumen selalu merasa puas. Setiap orang atau organisasi (perusahaan) harus bekerja dengan konsumen internal dan eksternal untuk memenuhi kebutuhan mereka bekerjasama dengan pemasok internal dan external demi terciptanya kepuasan konsumen. Terciptanya kepuasan konsumen dapat memberikan beberapa manfaat diantaranya: ${ }^{10}$

1. Hubungan perusahaan dengan konsumen menjadi harmonis.

2. Memberikan dasar yang baik bagi pembeli ulang.

3. Dapat mendorong terciptanya loyalitas konsumen.

4. Membentuk rekomendasi dari mulut ke mulut (word of mouth) yang menguntungkan perusahaan.

5. Reputasi menjadi baik dimata konsumen.

Jadi terciptanya kepuasan konsumen dapat dilakukan dengan memberikan pemenuhan terhadap kebutuhan konsumen baik bersifat fisik maupun pelayanan. Kepuasan tersebut juga memberikan manfaat salah satunya adalah mendorong loyalitas konsumen terhadap barang dan jasa sebuah perusahaan.

Dalam perspektif TQM (Total Quality Management) kualitas dipandang secara luas, yaitu tidak hanya aspek hasil yang ditekankan, tetapi juga meliputi proses, lingkungan dan manusia. Hal ini jelas tampak dalam defenisi yang dirumuskan oleh Goeth dan Davis yang dikutip Tjiptono bahwa kualitas merupakan suatu kondisi dinamis yang berhubungan dengan produk, jasa, manusia, proses, dan lingkungan yang memenuhi atau melebihi harapan. Sebaliknya, definisi kualitas yang bervariasi dari yang kontroversional hingga kepada yang lebih strategik. ${ }^{11}$

\footnotetext{
${ }^{6}$ Kotler dan Keller, Manajemen Pemasaran, Edisi 12, Jilid 1, Jakarta: PT.Indeks,2007, h. 35.

${ }^{7}$ Rambat Lupiyoadi, Manajemen Pemasaran Jasa. Jakarta : Salemba Empat, 2001, h. 98.

8Irawan Basu Swastha, Manajemen Pemasaran Modern, Yogyakarta, Edisi 2, 2000, h. 73

9John C Mowen, Michael, Minor, Perilaku Konsumen. Jakarta : Erlangga, Jilid Kedua, 2002, h. 77.

${ }^{10}$ Fandy Tjiptono,Dasar-Dasar Pemasaran. Jakarta : PT. Raja Grafindo, 2002, h. 35.

${ }^{11}$ Fandy Tjiptono, Gregorius Chandra, Pemasaran Strategik, Yogyakarta : Andi Offset, 2012, h.123.
} 
Menurut Garvin yang dikutip Tjiptono menyatakan bahwa terdapa lima perspektif mengenai kualitas, salah satunya yaitu bahwa kualitas dilihat tergantung pada orang yang menilainya, sehingga produk yang paling memuaskan preferensi seseorang merupakan produk yang berkualitas paling tinggi. ${ }^{12}$

Pengertian kualitas jasa atau pelayanan berpusat pada upaya pemenuhan kebutuhan dan keinginan pelanggan serta ketetapan penyampaiannya untuk mengimbangi harapan pelanggan.

Menurut Lewis \&Booms dalam Tjiptono mendefinisikan kualitas pelayanan secara sederhana, yaitu ukuran seberapa bagus tingkat layanan yang diberikan mampu sesuai dengan ekspektasi pelanggan. Artinya kualitas pelayanan ditentukan oleh kemampuan perusahaan atau lembaga tertentu untuk memenuhi kebutuhan yang sesuai dengan apa yang diharapkan atau diinginkan berdasarkan kebutuhan pelanggan/pengunjung. Dengan kata lain, faktor utama yang mempengaruhi kualitas pelayanan adalah pelayanan yang diharapkan pelanggan/pengunjung dan persepsi masyarakat terhadap pelayanan tersebut. Nilai kualitas pelayanan tergantung pada kemampuan perusahaan dan stafnya dalam memenuhi harapan pelanggan secara konsisten. ${ }^{13}$

Parasuraman, Zeithaml, Berry menjelaskan terdapat Lima dimensi dari kualitas jasa (service quality) yang didefinisikan yaitu $:^{14}$

1. Tangibles, atau bukti fisik yang meliputi fasilitas fisik (gedung, gudang dan lain sebagainya), perlengkapan dan peralatan yang dipergunakan (teknologi), serta penampilan pegawainya.

2. Reliability, atau keandalan meliputi kinerja harus sesuai dengan harapan pelanggan yang berarti ketepatan waktu, pelayanan yang sama untuk semua pelanggan, sikap simpatik dan akurasi yang tinggi.

3. Responsiveness, atau ketanggapan meliputi kemauan untuk membantu dan memberikan pelayanan yang cepat (responsive) dan tepat kepada pelanggan dengan informasi yang jelas.

4. Assurance, atau jaminan dan pengetahuan yaitu pengetahuan kesopansantunan dan kemampuan para pegawai perusahaan untuk menumbuhkan rasa percaya para pelanggan kepada perusahaan.

5. Empathy, yaitu syarat untuk peduli, memiliki pengertian dan pengetahuan tentang pelanggan, memahami kebutuhan pelanggan secara spesifik, serta memiliki waktu pengoperasian yang nyaman bagi pelanggan.

Dari banyaknya dimensi di atas maka peneliti akan mengambil lima dimensi dari kualitas pelayanan (SERQUAL) sebagai variabel dalam penelitian ini. Adapun kelima variabel itu adalah bukti fisik (Tangible), kehandalan (Reliability), daya tanggap (Responsiveness), jaminan (Assurance) dan terakhir empati (Empathy). Kelima variabel diatas akan ditempatkan sebagai variabel bebas yang mempengaruhi kepuasan konsumen.

\section{METODE PENELITIAN}

Penelitian ini dilakukan di dealer mobil Toyota PT. Wira Megah Toyota Profitamas Cabang Palangka Raya, yang beralamat di jalan Tjilik Riwut Km. 5 No. 8 Palangka Raya Kalimantan Tengah.

Populasi dalam penelitian ini adalah konsumen pengguna jasa dealer mobil Wira Megah Toyota Profitamas Palangka Raya. Adapun jumlah sampel yang diambil adalah menggunakan Accidental Sampling. ${ }^{15}$ Sampel dalam penelitian ini menurut hemat peneliti adalah sebagian

${ }^{12}$ Ibid., h. 143

${ }^{13}$ Ibid., h. 157

${ }^{14}$ Berry Zeithaml, Parasuraman, The Behavioral Consequences of Service Quality," Journal of Marketing, April 1996, 1996, h. 31-46.

${ }^{15}$ Sugiyono, Metode Penelitian Manajemen, Bandung : Alfabeta, 2013, h. 89. 
pelanggan dealer mobil Wira Megah Toyota Profitamas Palangka Raya sebanyak 100 orang. Metode penentuan sampel ini berdasarkan pertimbangan pelanggan dalam kurung waktu 2015 sampai dengan 2017.

Variabel penelitian merupakan suatu atribut atau obyek yang memiliki variasi tertentu yang ditetapkan oleh peneliti untuk dipelajari dan dapat ditarik kesimpulan. Variabel penelitian ini terdiri dari dua macam variabel, yaitu variabel terikat (dependent variable) atau variabel yang tergantung pada variabel lainnya, serta variabel bebas (independent variable) atau variabel yang tidak tergantung pada variabel yang lainnya. 16

Variabel dependen/endogen atau variabel terikat (Y1) atau (Y2) merupakan variabel yang dipengaruhi oleh variabel lain dan menjadi pusat perhatian peneliti. Hakekat sebuah masalah dapat mudah terlihat dengan mengenali berbagai variabel dependen yang digunakan dalam sebuah model. Variabilitas dari faktor inilah yang berusaha dijelaskan oleh peneliti. ${ }^{17}$ Variabel dependen yang digunakan dalam penelitian ini adalah kepuasan konsumen (Y1) dan niat datang kembali (Y2).

Adapun variabel independen atau variabel bebas (X) merupakan variabel yang mempengaruhi variabel dependen, baik yang mempengaruhi secara positif maupun negatif. Dalam script analysis, dapat terlihat bahwa variabel yang menjelaskan mengenai cara sebuah masalah dipecahkan adalah tidak lain variabel-variabel independen. Dimensi Variabel independen dalam penelitian ini adalah: ${ }^{18}$

1. Bukti Fisik (X1)

2. Kehandalan(X2)

3. Daya Tanggap(X3)

4. Jaminan(X4)

\section{HASIL PENELITIAN}

PT. Wira Megah Profitamas atau yang lebih dikenal dengan Wira Toyota merupakan salah satu dealer resmi di bawah Toyota Astra Motor untuk wilayah penjualan meliputi Kalimantan Selatan dan Kalimantan Tengah.

Pertama kali didirikan yaitu pada tahun 1986 perusahaan ini bernama CV. Wira Motor, seiring perjalanan waktu dan semakin meningkatnya penjualan kendaraan kemudian perusahaan berganti nama menjadi PT. Wira Megah Profitamas pada tahun 1989. Pada tahun 1998 kantor pusat berpindah ke alamat Jl. Jend. A Yani Km 10 No. 10 Banjarmasin, Kalimantan Selatan.

Saat ini Wira Toyota memiliki 8 cabang yagn tersebar di Kalimantan Selatan dan Kalimantan Tengah dengan 1 kantor pusat, 3 showroom dan 5 outlet yang melayani penjualan, layanan purna jual seperti perbaikan bodi dan pengecatan, servis dan pembelian suku cadang.

Deskripsi persepsi responden secara keseluruhan menunjukkan bahwa, responden setuju, Saya berniat melakukan servis mobil secara kontinyu atau berkala di Bengkel PT. Wira Megah Toyota Profitamas Palangka Raya (Y2.1), Saya selalu menggunakan produk servis hanya di Bengkel PT. Wira Megah Toyota Profitamas Palangka Raya (Y2.2), Saya berniat membeli jasa layanan tambahan hanya di Bengkel PT. Wira Megah Toyota Profitamas Palangka Raya (Y2.3), Setiap ada jasa layanan baru di bengkel maka saya selalu membeli jasa layanan Bengkel PT. Wira Megah Toyota Profitamas Palangka Raya (Y2.4), Saya berniat untuk menguji jasa layanan baru

\footnotetext{
16 Ibid.

${ }^{17}$ Ferdinand,Metode Penelitian Manajemen Pedoman Penelitian untuk Penulisan Skripsi, Tesis, dan Disertasi. Semarang: Badan Penerbit Universitas Diponegoro, 2011, h. 97. ${ }^{18}$ Ibid.
} 
Bengkel PT. Wira Megah Toyota Profitamas Palangka Raya (Y2.5), Setiap saat saya selalu mencoba pelayanan baru di Bengkel PT. Wira Megah Toyota Profitamas Palangka Raya dan menilai jasa layanan baru (Y2.6) merupakan faktor pembentuk Variabel Niat Datang Kembali.

\begin{tabular}{|c|c|c|c|c|c|c|c|c|c|c|c|}
\hline \multirow{3}{*}{$\begin{array}{c}\text { Indikator } \\
\text { Variabel/lem }\end{array}$} & \multicolumn{10}{|c|}{ Frekuensi Jawaban Responden (\%) } & \multirow{3}{*}{$\begin{array}{c}\text { Skor Rata- } \\
\text { rata } \\
\text { (Mẹan) }\end{array}$} \\
\hline & \multicolumn{2}{|c|}{ STS(1) } & \multicolumn{2}{|c|}{ TS(2) } & \multicolumn{2}{|c|}{ RG(3) } & \multicolumn{2}{|c|}{$\mathrm{S}(4)$} & \multicolumn{2}{|c|}{ SS(5) } & \\
\hline & $\mathrm{F}$ & $\%$ & $f$ & $\%$ & $f$ & $\%$ & $F$ & $\%$ & $f$ & $\%$ & \\
\hline Y2.1 & 9 & 9 & 1 & 1 & 2 & 2 & 45 & 45 & 43 & 43 & 4,12 \\
\hline Y2.2 & 5 & 5 & 2 & 2 & 1 & 1 & 40 & 40 & 52 & 52 & 4,32 \\
\hline Y2.3 & 5 & 5 & 3 & 3 & 3 & 3 & 39 & 39 & 50 & 50 & 4,26 \\
\hline Y2.4 & 6 & 6 & 0 & 0 & 3 & 3 & 42 & 42 & 49 & 49 & 4,28 \\
\hline Y2.5 & 7 & 7 & 4 & 4 & 2 & 2 & 36 & 36 & 51 & 51 & 4,20 \\
\hline Y2.6 & 5 & 5 & 2 & 2 & 3 & 3 & 51 & 51 & 39 & 39 & 4,17 \\
\hline & & & & $1 / 0$ & & & & & & & 4,23 \\
\hline
\end{tabular}

Penelitian ini menggunakan model persamaan struktural pendekatan Partial Least Square (PLS). Sebelum menganalisis, terlebih dahulu dilakukan pengujian atau evaluasi model empiris penelitian. Hasil pengujian model empiris penelitian ini dapat dilihat pada visualisasi Gambar 5.3 sebagai berikut.

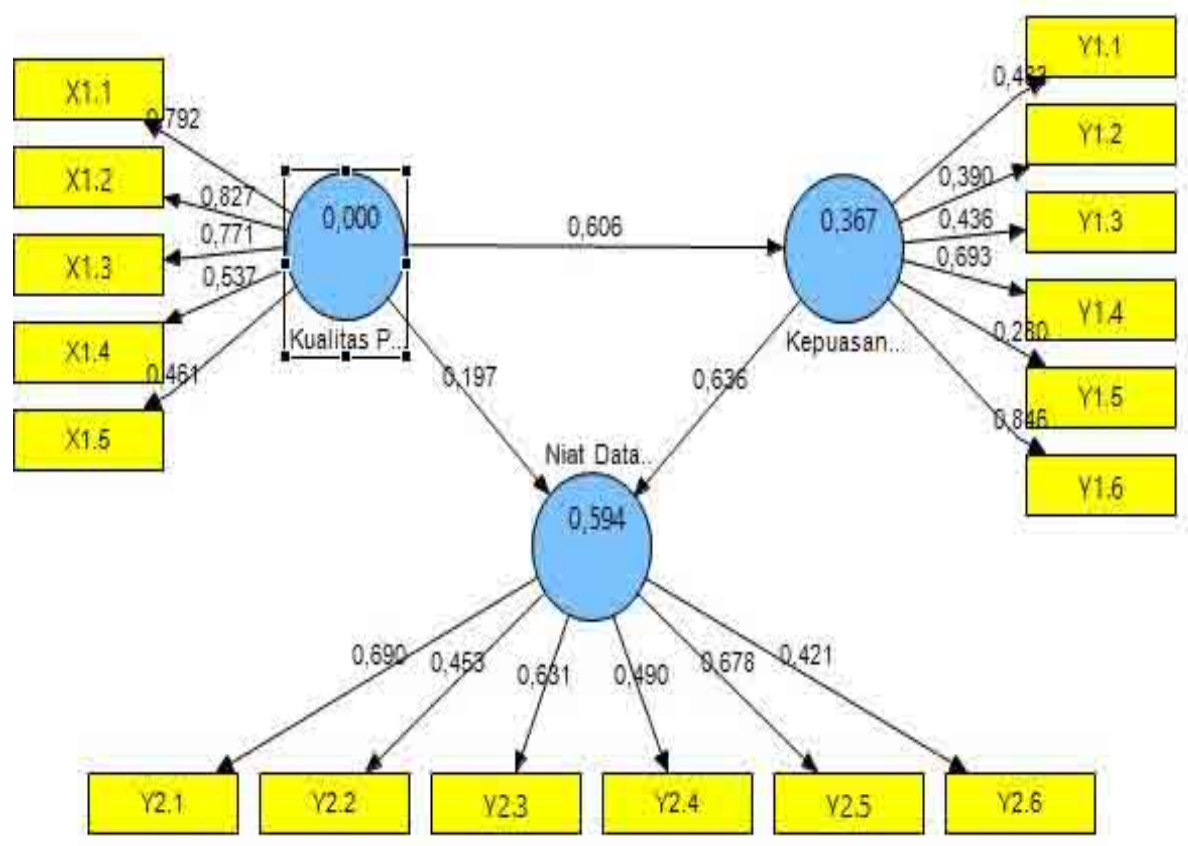

Hasil pengujian hipotesis dengan Partial Least Square menunjukkan bahwa dari tiga pengaruh langsung hipotesis dinyatakan signifikan. Sementara hasil pengujian dari satu pengaruh tidak langsung, hipotesis dinyatakan signifikan. Pengujian hipotesis pengaruh langsung dilakukan dengan menggunakan uji t (t-test) pada tiap-tiap jalur pengaruh antara variabel endogen dengan variabel eksogen, sedangkan untuk pengujian pengaruh tidak langsung 
dilakukan dengan menghitung Z-test dan P-value. Selanjutnya hasil pengujian hipotesis dapat dilihat sebagaimana visualisasi Tabel 5.14 sebagai berikut.

\begin{tabular}{|l|c|c|c|c|}
\hline \multicolumn{1}{|c|}{ Pengaruh Langsung } & $\begin{array}{c}\text { Koefisien } \\
\text { Jalur }\end{array}$ & $\begin{array}{c}\text { Standard } \\
\text { Deviation }\end{array}$ & $\begin{array}{c}\text { T- } \\
\text { Statistic }\end{array}$ & Keterangan \\
\hline $\begin{array}{l}\text { Kualitas Pelayanan } \rightarrow \text { Niat } \\
\text { Datang }\end{array}$ & 0,734589 & 0,082358 & 8,919416 & Signifikan \\
\hline $\begin{array}{l}\text { Kualitas Pelayanan } \rightarrow \text { Kepuasan } \\
\text { Konsumen }\end{array}$ & 0,428099 & 0,086601 & 4,943375 & Signifikan \\
\hline $\begin{array}{l}\text { Kepuasan Konsumen } \rightarrow \text { Niat } \\
\text { Datang }\end{array}$ & 0,097568 & 0,073343 & 1,330290 & $\begin{array}{c}\text { Tidak } \\
\text { Signifikan }\end{array}$ \\
\hline Pengaruh Tidak Langsung (H8) & $\begin{array}{c}\text { Koefisien } \\
\text { Jalur }\end{array}$ & $\mathrm{Z}$ Test & $\mathrm{P}$ Value & Keterangan \\
\hline $\begin{array}{l}\text { Kualitas Pelayanan } \rightarrow \text { Kepuasan } \\
\text { Konsumen } \rightarrow \text { Niat Datang }\end{array}$ & 0,3145 & 2,565 & 0,01 & Signifikan \\
\hline
\end{tabular}

Tabel 5.14 di atas, hasil analisis menunjukkan bahwa terdapat 2 (dua) pengaruh langsung signifikan. Sementara pengaruh tidak langsung menunjukkan signifikan sehingga dapat dikatakan bahwa Variabel Kepuasan Konsumen mampu memoderasi pengaruh antara Kualitas Pelayanan terhadap Niat Datang Kembali Konsumen Pada Bengkel Mobil Wira Megah Toyota Profitamas Cabang Palangka Raya.

Berdasarkan hasil analisis menunjukkan sub variabel dari kualitas pelayanan tertinggi dalam merefleksikan kepuasan pelanggan adalah bukti fisik (tangible) dengan nilai outer loading sebesar 0,867. Informasi tersebut menunjukkan bahwa secara statistik pada bukti fisik dapat mendeskripsikan variabel kualitas pelayanan tersebut. Sub variabel yang cukup besar kontribusinya terhadap peningkatan kepuasan pelanggan adalah reliability dan responsiveness dengan nilai outer louding masing-masing 0,854 dan 0,773.

Analisis menunjukkan indikator fasilitas penunjang sangat memadai merupakan skor faktor tertinggi dalam merefleksikan kepuasan pelanggan Bengkel Mobil Wira Megah Toyota Profitamas Cabang Palangka Raya dengan nilai outer loading sebesar 0,925. Informasi tersebut menunjukkan bahwa secara statistik pada fasilitas penunjang sangat memadai merupakan indikator tertinggi dalam mendeskripsikan variabel kepuasan pelanggan.

Demikian halnya dengan indeks rerata jawaban responden yang menyatakan bahwa, persepsi responden terhadap mencoba dan menguji jasa layanan baru sebagai dasar pengambilan keputusan sangat tinggi. Dengan kata lain dapat dijelaskan bahwa, kepuasan pelanggan yang tinggi akan berdampak langsung pada niat datang kembali secara individual. Secara eksplisit meningkatkan minat datang kembali pada Bengkel Mobil Wira Megah Toyota Profitamas Cabang Palangka Raya.

\section{IMPLIKASI PENELITIAN}

Penetian ini berimplikasi bahwa kualitas pelayanan berpengaruh terhadap loyalitas konsumen melalui kepuasan pelanggan pada Bengkel Toyota Palangka Raya sehingga setiap manajemen harus berfokus pada bagaimana meningkatkan kualitas pelayanan secara terus menerus. 


\section{KETERBATASAN PENELITIAN}

Penelitian ini dilakukan di dealer resmi Toyota Palangka Raya dengan responden dari pelanggan tetap Toyota. Ada beberapa keterbatasan baik dalam proses penetapan sampel yang hanya satu bengkel saja sehingga belum bisa mencerminkan bengkel lain secara keseluruhan.

\section{PENUTUP}

\section{Kesimpulan}

Dari hasil penelitian dan analisa di atas maka dapat ditarik kesimpulan penelitian sebagai berikut.

Kualitas Pelayanan yang direfleksikan dengan bukti fisik (tangibles) yang diberikan bengkel terhadap pelanggan berkontribusi positif pada kepuasan pelanggan secara individual yang tentu secara implisit dapat meningkatkan minat untuk datang kembali lebih tinggi pada bengkel mobil Wira Megah Toyota Profitamas Cabang Palangka Raya.

Kepuasan Pelanggan tinggi direpleksikan dengan peningkatan fasilitas yang memadai, dan berkontribusi searah dalam peningkatan kepuasan individual yang secara implisit mampu meningkatkan minat datang kembali pada bengkel mobil Wira Megah Toyota Profitamas Cabang Palangka Raya.

Niat Datang Kembali direfleksikan dengan menguji jasa layanan baru oleh pelanggan yang searah dengan kepuasan pelanggan berkontribusi positif pada minat datang kembali pada bengkel mobil Wira Megah Toyota Profitamas Cabang Palangka Raya. Dengan cara menguji jasa layanan baru maka pelanggan akan mengetahui tingkat layanan yang diberikan.

\section{Saran}

Bagi akademisi maupun pihak-pihak lain yang memerlukan informasi terkait dengan hasil penelitian ini, kiranya dapat memanfaatkan informasi ini yang sesuai dengan kebutuhan serta menggunakannya sebagai referensi ataupun bahan rujukan untuk penelitian-penelitian selanjutnya berkaitan dengan kualitas pelayanan, kepuasan konsumen dan niat datang kembali.

Bagi pimpinan PT. Wira Megah Toyota Profitamas Cabang Palangka Raya hendaknya pimpinan memperhatikan kepuasan pelanggan dengan memfokuskan perhatian pada peningkatan kualitas pelayanan tentunya akan berdampak pada niat datang kembali secara keseluruhan.

\section{DAFTAR PUSTAKA}

Ambika Shastri, 2012. Pengaruh Kualitas Pelayanan dan Lokasi Terhadap Kepuasan Konsumen pada Bengkel Motor Paramitha Graha Denpasar, Jurnal EMBA, Vol. 2 No. 2

Aviliani, R dan Wilfridus, L. 1997. Membangun Kepuasan Pelanggan Melalui Kualitas Pelayanan. Usahawan, No. 5.

Asghar dkk. 2011. Studi Pengaruh Layanan Pelanggan dan Kualitas Produk Terhadap Kepuasan Pelanggan dan Loyalitas. International Journal of Humanities and Social Science Vol. 1 No. 7; [Special Issue -June 2011].

Basu Swastha, Irawan. 2000. Manajemen Pemasaran Modern, Edisi 2. Yogyakarta.

Bitner,M.J.danZeithaml,V.A., 2003. ServiceMarketing (3 ${ }^{\text {rd }}$ ed.),Tata McGrawHill, New Delhi. 
Deniaty Nurani Fatimah, 114010127.2015. Pengaruh Kualitas Pelayanan Terhadap Kepuasan Pelanggan Dan Dampaknya Pada Loyalitas Pelanggan (Suatu survey pada Pelanggan Bengkel Mobil Non Members Tunas Toyota, Tbk Cabang Gatot Subroto, Bandung). Skripsi(S1) thesis, Fakultas Ekonomi Unpas.

Eswika Nilasari \& Istiatin. 2015. Pengaruh Kualitas Pelayanan Terhadap Kepuasan Konsumen Pada Dealer PT. Ramaya Motor Sukoharjo. Fakultas Ekonomi Universitas Islam Batik Surakarta, Indonesia. Vol 13, No 01 (2015): Jurnal Paradigma Vol. 13, No. 01.

Ferdinand. 2011. Metode Penelitian Manajemen Pedoman Penelitian untuk Penulisan Skripsi, Tesis, dan Disertasi. Badan Penerbit Universitas Diponegoro, Semarang.

Ghozali, Imam, 2006. Aplikai Analisis Multivarite dengan SPSS, Cetakan. Keempat, Badan Penerbit Universitas Diponegoro, Semarang.

Hamdani. 2006. Manajemen Pemasaran Jasa. Edisi. Kedua. Jakarta

Hartono. 2008. Analisis Data Statistika dan Penelitian, Yogyakarta: Pustaka Jogja

Kotler, Amstrong. 2001. Prinsip-prinsip Pemasaran, Edisi kedua belas, Jilid 1. Jakarta: Erlangga

Kotler, Philip. 2005. Manajemen Pemasaran, Jilid I dan II, PT. Indeks, Jakarta

Kotler, Philip dan Keller K Lane 2006. Manajemen Pemasaran. Jakarta: Ghalia. Indonesia.

Kotler dan Keller. 2007. Manajemen Pemasaran. Edisi 12, Jilid 1, PT.Indeks,. Jakarta.

Lovelock, Cistopher. 1992. Managing Service : Marketing, Operation and Human Resource. Jakarta: Salemba Empat.

Lupiyoadi, Rambat. 2001. Manajemen Pemasaran Jasa. Jakarta : Salemba Empat

Made Bagus R, Ida Bagus Sudiksa. 2014. Pengaruh Kualitas Layanan dan Kepuasan Pelanggan Terhadap Niat Pemakaian Ulang Jasa Service Pada Bengkel Toyota Auto 2000 Denpasar. Fakultas Ekonomi Universitas Udayana (Unud), Bali, Indonesia

Moenir, HAS. 1998. Manajemen Pelayanan Publik. Jakarta : Bina Aksara

Mowen, John, C dan Michael Minor. 2002. Perilaku Konsumen. Jilid Kedua. Jakarta : Erlangga

Murakami, Miki. 2015. Pengaruh Kualitas Pelayanan Terhadap Minat Beli Ulang Konsumen Pada Asuka Restoran Cibitung. Skripsi : Universitas Bina Nusantara.

Parasuraman, A., V.A. Zeithaml, and L.L Berry. 1988. "SERVQUAL: A multiple-item scale for measuring consumer perceptions of service quality", Journal of Retailling, Vol. 64 (Spring), pp. 12-40.

Penulisan Skripsi, Tesis, dan Disertasi Ilmu Manajemen, Edisi 3. Universitas Diponegoro Semarang. 
Ramdan. 2008. Hubungan Kualitas Jasa dan Kepuasan. Konsumen. (http://asep-m-ramdan.blogspot.com).

Rizan, M., dan Arrasyid, H. 2008. Analisis Asosiasi Merek, Nilai Produk, dan Kualitas Pelayanan, serta Pengaruhnya terhadap Kepuasan dan Loyalitas Konsumen sepeda Motor di Bekasi. Jurnal Siasat Bisnis, 12(2): 129-147.

Salim \& Woodward. 1992. Analisis Pelayanan Publik. Pustaka Pelajar.

Sugiyono. 2013. Metode Penelitian Manajemen. Bandung: Alfabeta.

Tjiptono, Fandy, Gregorius Chandra. 2007. Service, Quality Satisfaction. Yogyakarta. Andi Offset

Tjiptono, Fandy. 2005. Pemasaran Jasa, Malang: Bayumedia Publishing

Tjiptono, Fandy. 2002. Dasar-Dasar Pemasaran. Jakarta : PT. Raja Grafindo

Tjiptono, Fandy. 2004. Strategi Pemasaran, Edisi Kedua. Yogyakarta: Andi Offset

Tjiptono, Fandy dan Gregorius Chandra, 2012. Pemasaran Strategik. Yogyakarta : Andi Offset

Tjiptono, Fandy. 2014. Pemasaran Jasa. Jakarta: Gramedia Cawang

Umi Narimawati dkk. 2010. Riset Manajemen Sumber Daya Manusia. Jakarta : Agung Media.

Zeithaml, Berry and Parasuraman. 1996. The Behavioral Consequences of Service Quality," Journal of Marketing, April 1996, pp. 31-46. 